\title{
Optimization of Biogas Production in Dry Anaerobic Digestion of Swine Manure by the Use of Alkalinity Index to Monitor a Prototype Cylindrical Digester
}

\author{
Ondiba Hesborn Andole ${ }^{1, *}$, Zhongfang Lei ${ }^{2}$, Zhenya Zhang ${ }^{2}$, James Raude ${ }^{3}$, Christopher Kanali ${ }^{3}$ \\ ${ }^{1}$ Graduate School of Life and Environmental Sciences, University of Tsukuba, Tsukuba, Japan \\ ${ }^{2}$ Faculty of Life and Environmental Sciences, University of Tsukuba, Tsukuba, Japan \\ ${ }^{3}$ School of Biosystems and Environmental Engineering, Jomo Kenyatta University of Agriculture and Technology, Nairobi, Kenya \\ *Corresponding author: hondiba@gmail.com
}

\begin{abstract}
Anaerobic digestion (AD) is one of the best alternative sustainable technologies for energy production and recovery from organic solid wastes. Up to now dry AD has been commercialized in the treatment of municipal solid wastes. Little information could be found on the practical application of dry AD to manure wastes or waste activated sludge. This study aimed at testing the feasibility of using alkalinity to manage dry AD system for swine manure treatment and clarify its effect on the stability and efficiency of the newly-developed prototype cylindrical digester system. A prototype cylindrical digester with a diameter of $40 \mathrm{~mm}$ and a volume of 1.3 liters was designed and fabricated. It was operated under mesophilic conditions $\left(38^{\circ} \mathrm{C}\right)$. The alkalinity of manure was increased by 3000 $\mathrm{g} / \mathrm{L}\left(\mathrm{R}_{1}\right)$ and $6000 \mathrm{~g} / \mathrm{L}\left(\mathrm{R}_{2}\right)$ by adding sodium bicarbonate with the raw swine manure as the control $\left(\mathrm{R}_{0}\right)$. Results showed that $R_{1}$ and $R_{2}$ maintained a relatively higher level of alkalinity during the whole operation compared to the control $\left(\mathrm{R}_{0}\right)$. Only one peak appeared in biogas production for the control reactor $\left(\mathrm{R}_{0}\right)$ which almost ceased on day 12 , whereas $R_{1}$ and $R_{2}$ exhibited two biogas peaks. The 30 days' biogas yield for $R_{2}$ was $276.6 \mathrm{ml} / \mathrm{g}-\mathrm{VS}_{\text {added }}$ while $R_{1}$ was $204.8 \mathrm{ml} / \mathrm{g}-\mathrm{VS}_{\text {added }}$ which corresponds to an increase by 2.7- and 1.7- fold respectively as compared to the control $\left(\mathrm{R}_{0}\right)$. 2.2- and 4.1-fold increase in methane production was achieved in $\mathrm{R}_{1}$ and $\mathrm{R}_{2}$ respectively as compared to $\mathrm{R}_{0}$. This difference is most probably attributable to the high alkalinity in $\mathrm{R}_{1}$ and $\mathrm{R}_{2}$ that stabilized the digestion process and minimized the influence of $\mathrm{pH}$ variations on methanogenesis.
\end{abstract}

Keywords: alkalinity, dry anaerobic digestion, prototype cylindrical digester, swine manure

Cite This Article: Ondiba Hesborn Andole, Zhongfang Lei, Zhenya Zhang, James Raude, and Christopher Kanali, "Optimization of Biogas Production in Dry Anaerobic Digestion of Swine Manure by the Use of Alkalinity Index to Monitor a Prototype Cylindrical Digester.” Sustainable Energy, vol. 5, no. 1 (2017): 32-37. doi: 10.12691/rse-5-1-5.

\section{Introduction}

Kenya, a sub-Saharan African country, has a national electrification level of $36 \%$ and thus only about $12.6 \%$ of the rural households have access to electricity [1]. Nationally, 69\% of all households use firewood for cooking [2]. Inadequate power supply capacity due to rise in demand for electricity, which is growing faster than the ability to install additional generation plants is one of the greatest challenges. Furthermore, over-dependence on hydro-power, which exposes the country to power rationing due to extreme weather conditions that result in drought worsens this situation. The need for alternative energy resources is therefore imperative.

Dry Anaerobic Digestion (AD) has attracted increasingly extensive attentions in the studies of biogas fermentation with advantages of water-saving, higher volumetric organic loading rate, higher biogasification performance, smaller reactor capacity requirement, less energy used for heating, easier handle ability of digestate, and higher energy recovery as compared to wet $\mathrm{AD}[2,3]$. This process is more feasible to a wide range of organic wastes including waste water sludge from industries with the recovery of renewable energy and reduction in pollution load [4]. The process also results in a lower production of leachate and easy handlings of digested residues that can further be treated by aerobic composting processes and used as organic fertilizer [5]. In this regard, dry $A D$ is a remarkable method that could offer potential by-products such as fertilizer for the large population of farmers as well as energy generation. It is the most promising technology based on its characteristics and advantages. Over the past 20 years, different commercialized dry AD systems have been developed and marketed by different companies in Europe. The Kompogas, Valorga and Dranco dry AD systems are the most prevalent and have been mainly used for commercially processing of municipal solid waste, kitchen waste, or yard waste [6]. However, up to now there is no commercial dry $A D$ system for treatment of manure waste.

Alkalinity is often referred to as buffer capacity in AD, which is the equilibrium of carbon dioxide and bicarbonate 
ions that provide resistance to significant and rapid changes in $\mathrm{pH}$. The buffering capacity is therefore proportional to the concentration of bicarbonate and is a reliable method of measuring digester imbalance. Increasing a low buffering capacity is best accomplished by reducing the Organic loading Rate (OLR), although a more rapid approach is the addition of strong bases or carbonate salts to remove carbon dioxide from the gas space and convert it to bicarbonate, or alternatively bicarbonate can be added directly. A more sensitive parameter for monitoring digesters and measuring process stability is the VFA/alkalinity ratio: when this ratio is less than 0.35 0.40 (equiv. acetic acid/equiv. $\mathrm{CaCO}_{3}$ ), the process is considered to be operating favorably without acidification risk [7].

[8] found out that the use of anaerobic baffled reactor as pretreatment prevented alkalinity shocks and acidity, avoiding sudden variation in $\mathrm{pH}$, which positively assisted the maintenance of microbial activity, especially methanogenic archaea, due to the system buffering. The buffering conditions had positive influence on biogas production. [9] and [10] proposed the control of AD based on alkalinity titration. Automatic control of anaerobic digestion based on alkalimetric measurements was proposed by [11] and [12]. Similarly to VFA measurements, the utility of alkalinity as a control parameter in anaerobic digesters has not been established.

More rapid techniques are needed to avoid significant process deterioration and failure of dry $\mathrm{AD}$ process. Previously, researchers have put efforts to develop better indicators for process monitoring. An ideal indicator would be easy to measure, available on a real-time and perhaps on-line basis, and, of course, would have intrinsic meaning as it must reflect the current metabolic status of the system. Feasible and relevant indicators of the AD process condition have been argued for decades [13]. Little systematic information could be found about the management of dry AD systems.

According to previous research, dry $\mathrm{AD}$ has been commercialized in the treatment of municipal solid waste. Little information could be found on the practical application of dry AD to manure wastes or waste activated sludge, possibly due to their high nitrogen content which easily brings about high concentration of ammonia and large fluctuation in system $\mathrm{pH}$ resulting in low methane production or even AD failure. Moreover, little information is also available on how to use the alkalinity index to control and manage dry AD. Thus the objective of this study was to test the feasibility of using alkalinity to manage dry $\mathrm{AD}$ system for swine manure treatment and to clarify its effect on the stability and efficiency of a newlydeveloped prototype cylindrical digester system.

\section{Materials and Methods}

\subsection{Swine Manure}

The swine manure used in this study was obtained from a pig farm located in Tsukuba, Ibaraki, Japan. The pigs were raised in traditional pig houses paved with chopped straw bedding material to absorb urine. The manure was therefore collected in solid state, thoroughly mixed to achieve homogeneity and stored at $4^{\circ} \mathrm{C}$ before the experiments. The main characteristics of the swine manure are shown in Table 1.

Table 1. Characteristics of swine manure used in this study

\begin{tabular}{cc}
\hline Parameters & Average value \\
\hline TS & $27.9 \%$ \\
VS & $217.0 \mathrm{~g} / \mathrm{L}$ \\
Alkalinity & $11300.0 \mathrm{mg} / \mathrm{L}$ \\
pH & 7.0 \\
Total VFAs & $21.6 \mathrm{mgC} / \mathrm{g}-\mathrm{VS}$ \\
\hline
\end{tabular}

TS-Total solids, VS-Volatile solids, VFAs-Volatile fatty acids

\subsection{Experimental Setup}

The digester used in this study was a 1.3-L clear PVC cylindrical pipe with a working volume of $1 \mathrm{~L}$. It consisted of a sampling outlet at the center, a gas outlet port, digestate outlet and feed inlet as shown in Figure 1. A water bath constantly maintained at mesophilic temperatures of about $38^{\circ} \mathrm{C}$ was placed besides the reactor. This water was pumped round the digester to maintain a constant temperature in the digester. The gas outlet port on the digester was connected to a water displacement gas collection system consisting of sodium bicarbonate $\left(\mathrm{NaHCO}_{3}\right)$ solution and a graduated cylinder for measuring gas volume. All the outlet and the inlet ports were maintained at gas tight condition to ensure anaerobic conditions within the digester.

\subsection{Experimental Design}

The digester was subjected to several tests to ensure that it was gas tight. The TS of swine manure was adjusted to about $15 \%$ before dosing into the digester. The swine manure was then loaded into the digester until the digester was full. The initial total alkalinity, $\mathrm{pH}$ VS, TS and VFAs were determined on the day when the experiment began. The experiments were divided into 3 groups. The first experiment $\left(\mathrm{R}_{0}\right)$, i.e. the control experiment, had swine manure directly fed into the digester with its alkalinity unadjusted. In the second experiment $\left(R_{1}\right)$,

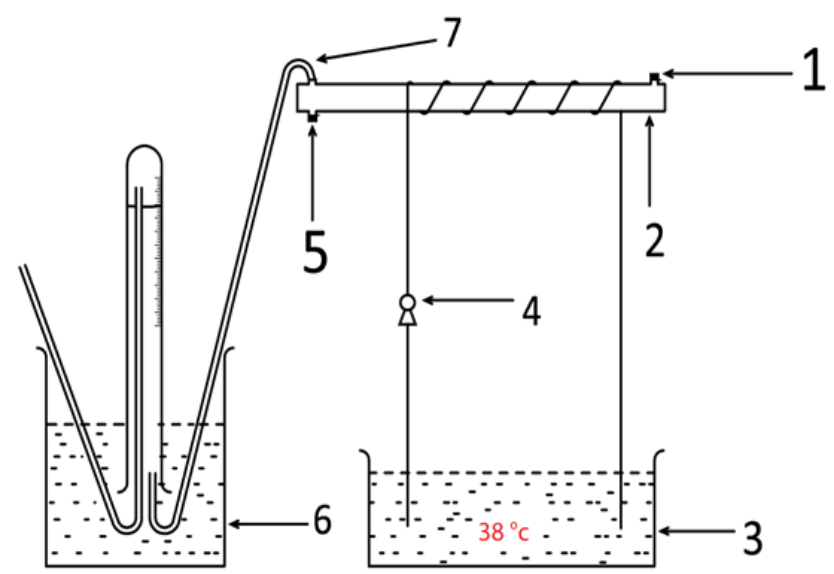

Figure 1. A schematic diagram of the dry anaerobic digester. 1-Manure input, 2-Prototype cylindrical digester, 3-Water bath, 4-Pump, 5Digestate output, 6-Gas collection (water displacement method), 7- Gas pipe 
The initial alkalinity of swine manure was increased by $3000 \mathrm{~g} / \mathrm{L}$ before feeding into the digester. And the third experiment $\left(R_{2}\right)$ had the initial alkalinity increased by $6000 \mathrm{~g} / \mathrm{L}$ before feeding into the digester. Digestate was sampled out after every 2 days with its alkalinity, $\mathrm{pH}$, VS, TS and VFAs being determined. The amount of biogas produced was determined at an interval of 24 hours with its methane yield checked. The experiments were terminated when no significant gas production was detected. The efficiency of the systems was determined and compared at operation duration of 30 days.

\subsection{Analytical Methods}

Total solids (TS) and volatile solids (VS) were determined using standard techniques [14]. Total alkalinity was determined by titration method to an end point $\mathrm{pH}$ of 4.3. Biogas production was measured by water displacement method. The volume of biogas was directly read from the graduated cylinder. $\mathrm{pH}$ was measured directly in the digestate using a semi-solid $\mathrm{pH}$ meter (Testo 206, Germany). Gas composition was determined using a gas chromatography (GC-8A, SHIMAZU, Japan) equipped with a thermal conductivity detector $\left(80^{\circ} \mathrm{C}\right)$ and a Porapak Q column $\left(60^{\circ} \mathrm{C}\right)$. Nitrogen $\left(\mathrm{N}_{2}\right)$ was used as the carrier gas.

For VFAs analysis, $4 \mathrm{~g}$ of well mixed sample was diluted with $40 \mathrm{ml}$ of deionized water. The mixture was centrifuged at $9900 \mathrm{rpm}$ and $4^{\circ} \mathrm{C}$ for $20 \mathrm{~min}$ after being shaken well. The resultant supernatant was filtrated through filter membranes with a pore size of $0.22 \mu \mathrm{m}$. 3\% phosphoric acid solution was added to the filtrate to acidify samples at a volume ratio of 1:9. Gas chromatograph (GC-8A, Shimadzu) equipped with Unisole F-200 30/60 column and flame ionization detector (FID) was used for quantification of VFAs, including HAc, $\mathrm{HPr}, \mathrm{i}-\mathrm{HBu}, \mathrm{n}-\mathrm{HBu}, \mathrm{i}-\mathrm{HVa}$ and n-HVa. l $\mu \mathrm{m}$ prepared samples were injected to GC-FID directly with a retention time of 12 min. Nitrogen was used as carrier gas. The temperature of injection port and column were maintained at $180^{\circ} \mathrm{C}$ and $150^{\circ} \mathrm{C}$, respectively.

\section{Results and Discussions}

\subsection{Alkalinity and pH Variation}

A high alkalinity trend was observed in $R_{1}$ and $R_{2}$ when compared to the control $\left(\mathrm{R}_{0}\right)$ as shown in Figure 2.

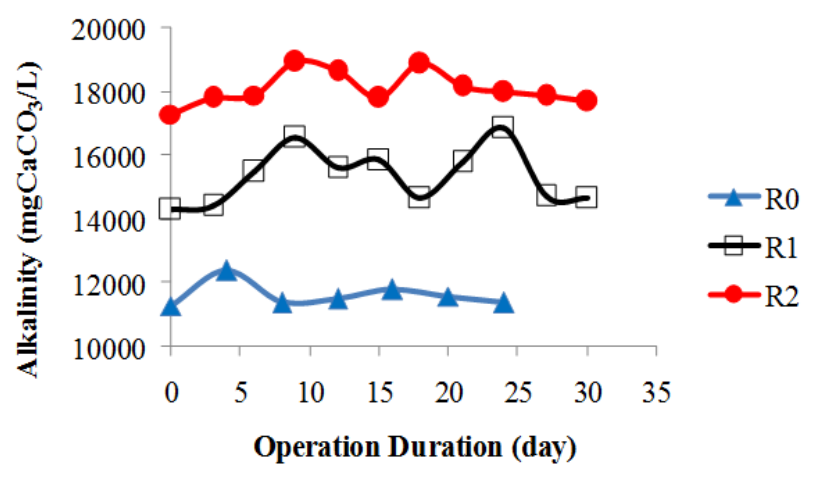

Figure 2. Changes in alkalinity during dry $\mathrm{AD}$ of swine manure
This was probably because $\mathrm{NaHCO}_{3}$ was added in $\mathrm{R}_{1}$ and $\mathrm{R}_{2}$ which boosted the total alkalinity. There were two alkalinity peaks in $\mathrm{R}_{1}$ and $\mathrm{R}_{2}$ that almost corresponded to the respective daily biogas production peaks. In the first 30 days, $R_{2}$ had the highest average alkalinity of 18,090.9 $\mathrm{mg} / \mathrm{L}$ while $\mathrm{R}_{1}$ and $\mathrm{R}_{0}$ had $15,196.4 \mathrm{mg} / \mathrm{L}$ and 11,628.6 $\mathrm{mg} / \mathrm{L}$ respectively. In $\mathrm{R}_{1}$ and $\mathrm{R}_{2}$, alkalinity was observed to increase up to the biogas peak and later reduced after the peak possibly due to utilization of VFAs to form methane gas that reduced the acid levels in the reactor. Also, the production of ammonia might elevate the system pH.

In all the three reactors, $\mathrm{pH}$ decreased during the first 4 days of operation as shown in Figure 3. We can easily understand that the pHs decreased first due to the hydrolysis and acidification process, and then increased to a relatively stable value during the methanogenesis process. With a low buffer capacity, the $\mathrm{pH}$ of $\mathrm{R}_{0}$ decreased dramatically to less than 6.0 and then increased slightly to 6.3 however, it couldn't rise more. This may be attributed to the production and accumulation of VFAs that increased the acid levels in the digester which inhibited the activity of methanogenic bacteria. In $\mathrm{R}_{1}$ and $\mathrm{R}_{2}$, the $\mathrm{pH}$ was able to rise again to an average of 7.1 and 6.8 respectively due to high buffer capacity that was able to neutralize the acids produced. According to [5] maximal biogas yield in anaerobic digestion was found to be in the $\mathrm{pH}$ range of 6.5 - 7.5. The average $\mathrm{pHs}$ in $\mathrm{R}_{1}$ (6.8) and $R_{2}$ (7.1) were detected to be able to maintain within this $\mathrm{pH}$ range and hence maximum yield of biogas as compared to $\mathrm{R}_{0}$ (6.3). From these results, it can be easily seen that increase in alkalinity is beneficial to maintain stable $\mathrm{pH}$ within the optimum condition for biogas production, even in dry AD process.

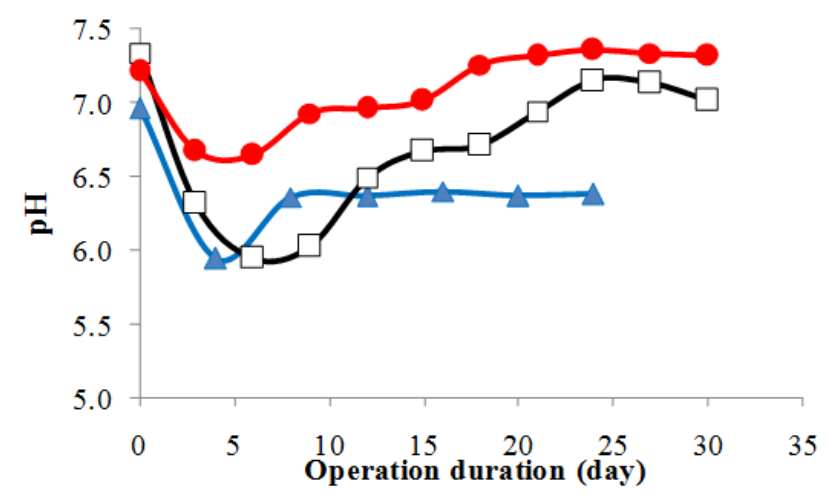

Figure 3. Changes in $\mathrm{pH}$ during dry $\mathrm{AD}$ of swine manure

\subsection{Biogas Production}

$\mathrm{R}_{1}$ and $\mathrm{R}_{2}$ had two biogas peaks observed on day 10, 26 and day 11, 20 respectively as shown in Figure 4.

The 30 days' biogas yield for $R_{2}$ was $276.6 \mathrm{ml} / \mathrm{g}$ $\mathrm{VS}_{\text {added }}$ while $\mathrm{R}_{1}$ was $204.8 \mathrm{ml} / \mathrm{g}-\mathrm{VS}_{\text {added }}$ which corresponds to an increase by $2.7-$ and $1.7-$ fold respectively as compared to the control $\mathrm{R}_{0}(74.8 \mathrm{ml} / \mathrm{g}$ $\mathrm{VS}_{\text {added }}$ ). This was possibly due to high alkalinity in $\mathrm{R}_{1}$ and $\mathrm{R}_{2}$ that was able to maintain the $\mathrm{pH}$ within optimum range in the digester which favored methanogenesis process. $\mathrm{R}_{0}$ had only one biogas peak on day 5 and methanogenesis stopped on day 12, probably due to its 
low buffering capacity and hence inhibition from the VFAs accumulation which increased the acid levels thus lower $\mathrm{pH}$ in the digester. Within 30 days, $\mathrm{R}_{1}$ and $\mathrm{R}_{2}$ produced 22.8 and 31.9 liters of biogas which corresponds to 1.6- and 2.7-fold increase in biogas production respectively as compared to $\mathrm{R}_{0}$ (8.7 liters). These findings are consistent with [15] who obtained the highest biogas production from $\mathrm{pH} 7.0$ reactor in comparison to other different $\mathrm{pH}$ reactors. On day 30, biogas production had stopped in $\mathrm{R}_{2}$ while there was still biogas produced in $\mathrm{R}_{1}$ as shown in Figure 5 , therefore $R_{2}$ had a shorter biogasification period than $\mathrm{R}_{1}$.

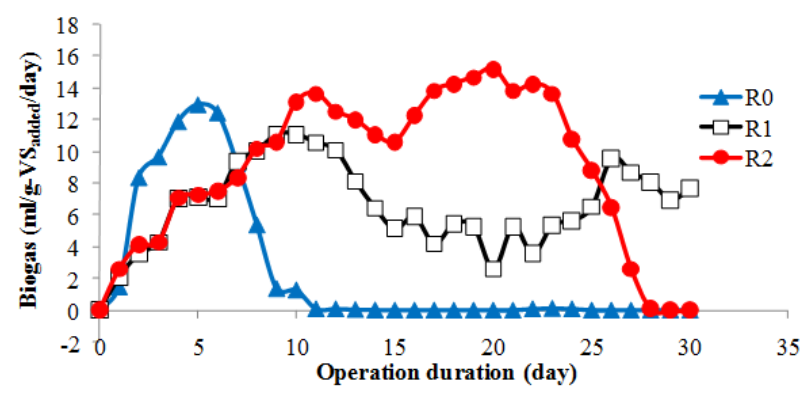

Figure 4. Daily biogas production during dry $\mathrm{AD}$ of swine manure

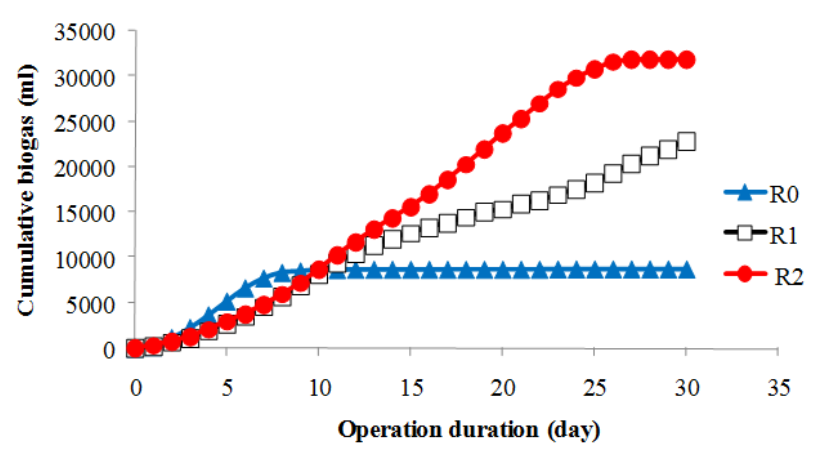

Figure 5. Cumulative biogas production during dry AD of swine manure

\subsection{Methane production}

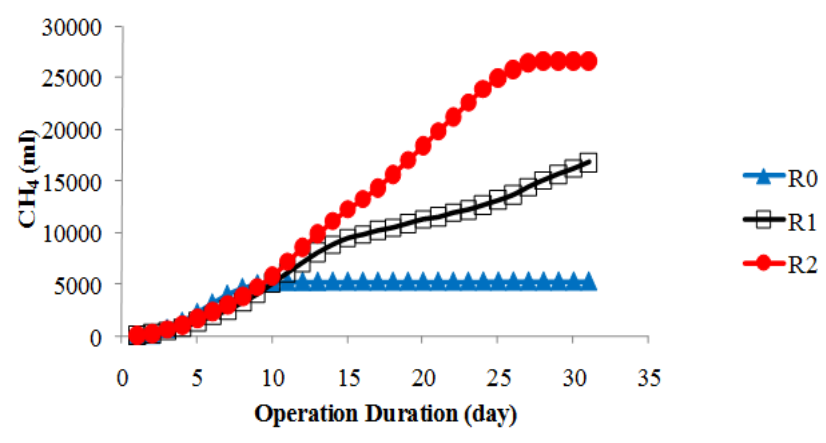

Figure 6. Cumulative methane of biogas produced during dry AD of swine manure

$\mathrm{R}_{2}$ had the highest methane yield of $230.6 \mathrm{ml} / \mathrm{g}-\mathrm{V}_{\text {Sadded }}$, as compared to $\mathrm{R} 1$ (151.0 $\left.\mathrm{ml} / \mathrm{g}-\mathrm{VS}_{\text {added }}\right)$ and $\mathrm{R}_{0}(45.1$ $\mathrm{ml} / \mathrm{g}-\mathrm{VS}_{\text {added }}$ ) respectively for the first 30 days. $\mathrm{R}_{1}$ and $\mathrm{R}_{2}$ produced 16.8 and 26.6 liters of methane; this corresponds to 2.2- and 4.1-fold increase in methane production respectively as compared to $\mathrm{R}_{0}$ (5.3 liters) within the first 30 days. In Figure $6, \mathrm{R}_{0}$ was observed to be stabilized at around 5 liters which was the lowest as compared to $\mathrm{R}_{1}$ and $R_{2} \cdot R_{1}$ had not yet stabilized due to its continuous production of methane after the 30 th day. $R_{2}$ stabilized at around 26.6 liters which was the highest achieved in these experiments.

There was a significant increase in average methane content from control $R_{0}(60.3 \%)$ to $R_{1}(73.7 \%)$ and $R_{2}$ (83.4\%) after initial alkalinity of swine manure being elevated (shown in Figure 7). Results from this work agrees with [16] who found out that $\mathrm{CH}_{4}$ content significantly increase to $74 \%$ under alkaline condition as compared to other conditions.

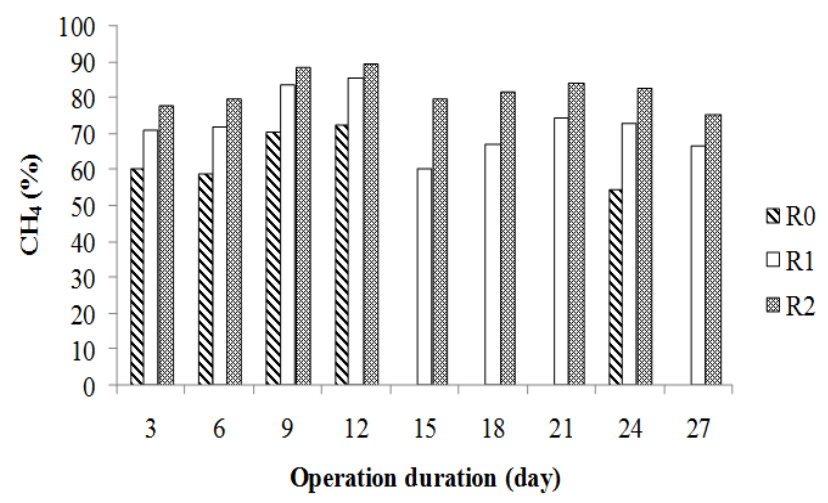

Figure 7. Methane content of biogas produced during dry AD of swine manure

\subsection{Volatile Solids Removal}

One of the most useful parameters for evaluating the efficiency of anaerobic digestion is the reduction in VS. VS are decreased due to solubilization of particulate organics for biogas production. 2.2- and 0.9-fold reductions in VS were achieved in $R_{2}$ and $R_{1}$ respectively as compared to $R_{0}$. This is shown in Figure $8 . R_{2}$ had the highest VS conversion efficiency among the 3 tested reactors.

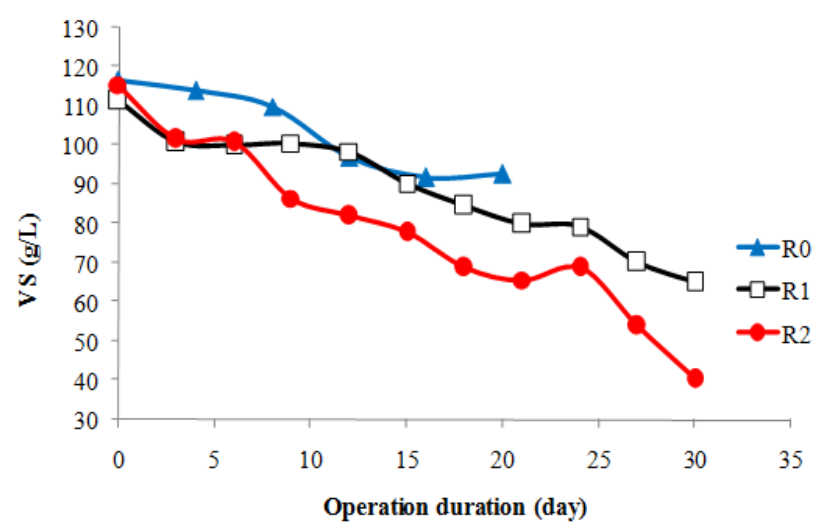

Figure 8. Changes in VS during dry $\mathrm{AD}$ of swine manure

This may be due to the high alkaline environment in $\mathrm{R}_{2}$ that facilitated optimum condition for degradation and solubilization of the organics which enhanced biogas production. Initially, $\mathrm{R}_{0}, \mathrm{R}_{1}$ and $\mathrm{R}_{2}$ had a VS concentration of $116.65 \mathrm{~g} / \mathrm{L}, 111.36 \mathrm{~g} / \mathrm{L}$ and $115.41 \mathrm{~g} / \mathrm{L}$, respectively. On the $30^{\text {th }}$ day, $\mathrm{R}_{0}, \mathrm{R}_{1}$ and $\mathrm{R}_{2}$ had a VS concentration of $92.82 \mathrm{~g} / \mathrm{L}, 65.10 \mathrm{~g} / \mathrm{L}$ and $40.34 \mathrm{~g} . \mathrm{L}$ respectively. $\mathrm{R}_{2}$ had the lowest VS content in the final effluent after 30 days' digestion period whereas $\mathrm{R}_{0}$ had the highest VS content. 


\subsection{Profiles of Volatile Fatty Acids}

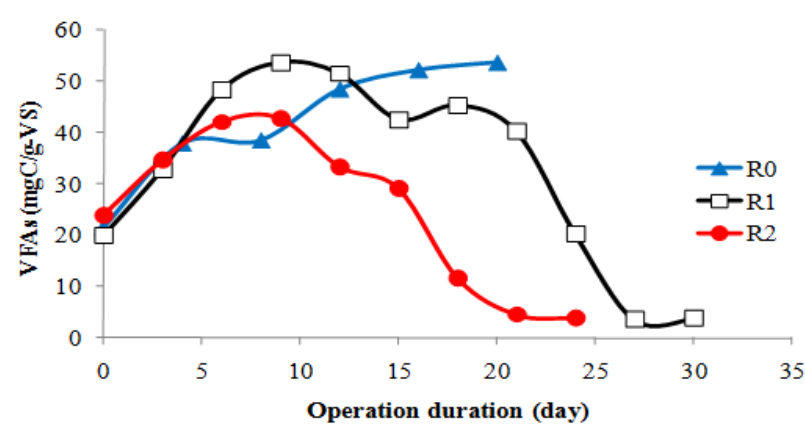

Figure 9. Changes in total VFAs during dry AD of swine manure
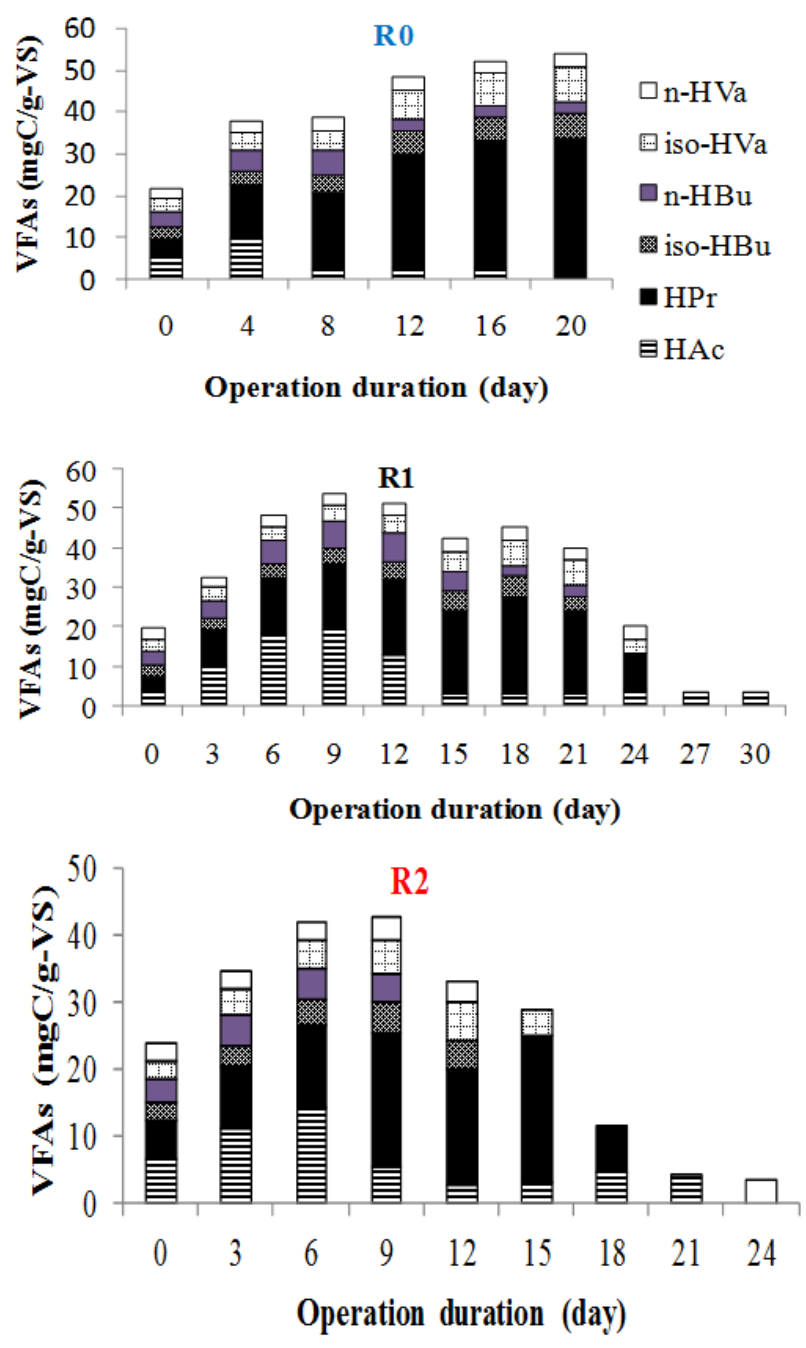

Figure 10. VFAs profiles during dry AD of swine manure

Initially in $\mathrm{R}_{0}, \mathrm{R}_{1}$ and $\mathrm{R}_{2}$, VFAs increased during the acidogenesis phase as shown in Figure 9. In $\mathrm{R}_{1}$, total VFAs increased to $53.71 \mathrm{mgC} / \mathrm{g}$-VS whereas in $\mathrm{R}_{2}$ it increased to $42.91 \mathrm{mgC} / \mathrm{g}-\mathrm{VS}$ on the $9^{\text {th }}$ day. Later on, the total VFAs decreased to $3.90 \mathrm{mgC} / \mathrm{g}-\mathrm{VS}$ in $\mathrm{R}_{1}$ and 3.72 $\mathrm{mgC} / \mathrm{g}-\mathrm{VS}$ in $\mathrm{R}_{2}$ on the $30^{\text {th }}$ day. This decrease is probably attributable to the utilization of VFAs for methane production in the subsequent methanogenesis phase. The high buffering capacity in $\mathrm{R}_{1}$ and $\mathrm{R}_{2}$ provided an optimum environment for the methanogenesis process. In $\mathrm{R}_{0}$, total VFAs did not subsequently decrease after the continuous increase to $53.63 \mathrm{mgC} / \mathrm{g}$-VS on the $20^{\text {th }}$ day, this therefore caused its accumulation and hence inhibition on the methanogenesis process due to acidic environment.

From the VFAs profiles in Figure 10, accumulation of propionic acid (HPr) was observed in R0 which could be associated with the slow HPr degradation. HPr degradation depends on the activities of propionic acid oxidizing bacteria (POB) which are slow-growth microorganisms and can be sensitive to reactor operating conditions $[17,18]$. [19] reported that $\mathrm{pH}$ was an important parameter affecting growth of a mixed POB culture and the optimal $\mathrm{pH}$ range for its growth was $6.80-8.50$. $\mathrm{R}_{0}$ with low buffering capacity and an average $\mathrm{pH}$ of 6.3 was outside the optimal range as compared to 6.8 and 7.1 for $R_{1}$ and $R_{2}$, respectively. This probably led to low degradation of HPr that increased its accumulation further lowering reactor $\mathrm{pH}$ and hence inhibiting the methanogesis process. These results are consistent with [20] and [21] who found that accumulation of VFAs especially HPr led to failure in AD systems.

\section{Conclusions}

Energy is the heart of most critical economic, environmental and developmental issues facing developing countries today. The current patterns of energy production and consumption in Kenya are unsustainable and threaten the environment on both local and global scales. Biogas production through AD provides a sustainable source of energy and the bio-slurry produced enriches the soil for agricultural activities. It also provides an opportunity to treat and re-utilize organic wastes and reduces land use problems associated with the disposal of organic waste. This study investigated the effect of different levels of alkalinity on the efficiency of dry anaerobic digestion process of swine manure.

The following major conclusions could be arrived at.

(1). A high alkalinity trend was observed in $R_{1}$ and $R_{2}$ when compared to the control $\left(\mathrm{R}_{0}\right)$. In the first 30 days, $\mathrm{R}_{2}$ had the highest average alkalinity of $18,090.9 \mathrm{mg} / \mathrm{L}$ while $\mathrm{R}_{1}$ and $\mathrm{R}_{0}$ had 15,196.4 mg/L and 11,628.6 mg/L respectively.

(2). $R_{2}(+6000 \mathrm{mg} / \mathrm{L})$ exhibited a stable digestion process as compared to $R_{1}(+3000 \mathrm{mg} / \mathrm{L})$ and $\mathrm{R}_{0}$ (control). The 30 days' biogas yield for $\mathrm{R}_{2}$ was $276.6 \mathrm{ml} / \mathrm{g}-\mathrm{VS}_{\text {added }}$ while $\mathrm{R}_{1}$ was $204.8 \mathrm{ml} / \mathrm{g}-\mathrm{VS}_{\text {added }}$ which corresponds to an increase by 2.7 - and 1.7- fold respectively as compared to the control $\mathrm{R}_{0}\left(74.8 \mathrm{ml} / \mathrm{g}-\mathrm{VS}_{\text {added }}\right) . \mathrm{R}_{1}$ and $\mathrm{R}_{2}$ produced 16.8 and 26.6 liters of methane; this corresponds to 2.2- and 4.1-fold increase in methane production respectively as compared to $\mathrm{R}_{0}$ (5.3 liters) within the first 30 days.

(3). A high rate of VS removal was detected in $\mathrm{R}_{2}$ which had the highest VS conversion efficiency among the 3 tested reactors. 2.2- and 0.9-fold reductions in VS were achieved in $\mathrm{R}_{2}$ and $\mathrm{R}_{1}$ respectively as compared to $\mathrm{R}_{0}$. This may be due to the high alkaline environment in $\mathrm{R}_{2}$ that facilitated optimum condition for degradation and solubilization of the organics which enhanced biogas production.

(4). VFAs accumulation especially HPr is one of the major causes of $\mathrm{AD}$ system failure. $\mathrm{R}_{0}$ achieved an average $\mathrm{pH}$ of 6.3 that was outside the optimal range for HPr degradation as compared to 6.8 and 7.1 in $R_{1}$ and $R_{2}$ respectively. This probably led to low degradation of $\mathrm{HPr}$ that increased its accumulation. The accumulation of VFAs further lowered reactor $\mathrm{pH}$ and hence inhibited the 
methanogesis process as observed from the low biogas yield in $\mathrm{R}_{0}$.

\section{References}

[1] World Bank, Sustainable Energy for All (SE4ALL) database from the SE4ALL Global Tracking Framework led jointly by the World Bank, International Energy Agency, and the Energy Sector Management Assistance Program. 2014.

https://data.worldbank.org/indicator(Accessed 24th, December 2017)

[2] The International Renewable Energy Agency (IRENA), 2010.Renewable Energy Country Profiles.

http://www.irena.org/home/index.aspx?PriMenuID=12\&mnu=Pri( Accessed $20^{\text {th }}$, October 2016).

[3] Lei Z., Zhang Z., Huang W., Cai W., 2015. Recent Progress on Dry Anaerobic Digestion of Organic Solid Wastes: Achievements and Challenges. Current Organic Chemistry19, 400-412.

[4] De Baere L., 2000. Anaerobic Digestion of Solid Waste: State-ofthe-art. Water Science and Technology 41(3), 283-290.

[5] Liu G., Peng X., Long T R., 2006. Advance in High Solid Anaerobic Digestion of Organic Fraction of Municipal Solid Waste. Journal of Central South University of Technology 13, 416-420.

[6] Liu Z G., Zhu H.G.,Wan G.B., Zhang Y., 2009. Effect of Ratio of Manure to Crop on Dry Anaerobic Digestion for Biogas Production. Journal of Chinese Society of Agricultural Engineering 25 (4), 151-157.

[7] Li Y., Park S.Y., Zhu J., 2011. Solid-state Anaerobic Digestion for Methane Production from Organic Waste. Renewable Sustainable and Energy 15, 821-827.

[8] Zickefoose C., Hayes R. B., 1976. Anaerobic Sludge Digestion: Operations Manual. EPA 430/9-76-001.

[9] Erlon L. P., Claudio M.M., Campos.,Fabricio M., 2013. Physicochemical Study of $\mathrm{pH}$, Alkalinity and Total Acidity in a System Composed of Anaerobic Baffled Reactor (ABR) in series with Upflow Anaerobic Sludge Blanket Reactor (UASB) in the Treatment of Pig Farming Wastewater. ActaScientiarum- Technology $35,477-483$.

[10] Jenkins S.R., Morgan J.M., Sawyer C.L., 1983. Measuring Anaerobic Sludge Digestion and Growth by a Simple Alkalimetric Titration. Water Pollution Control Federation 55, 448-453.
[11] Ripley L. E., Boyle W.C., Converse J. C., 1986. Improved Alkalimetric Monitoring for Anaerobic Digestion of High-strength Wastes.Water Pollution Control Federation 58, 406- 411.

[12] Rozzi A., Di Pinto A.C., Brunetti A., 1985. Anaerobic Process Control by Bicarbonate Monitoring. Environmental Technology 6, 594-601.

[13] Colin F., Ferrero G. L., Ferranti M. P., Naveau H., 1984. Anaerobic Digestion and Carbohydrate Hydrolysis of Waste. Elsevier Applied Science Publishers, London. 391-394

[14] Switzenbaum M.S., Giraldo-Gomez E., Hickey R.F., 1990. Review: Monitoring of The Anaerobic Methane Fermentation Process. Enzyme and Microbial Technology 12, 722-730.

[15] APHA, 2012. Standard methods for the examination of water and wastewater, 22nd edition edited by E. W. Rice, R. B. Baird, A. D. Eaton and L. S. Clesceri. American Public Health Association (APHA), American Water Works Association (AWWA) and Water Environment Federation (WEF), Washington, D.C., USA.

[16] Zhou J., Zhang R., Liu F., Yong X., Wu X., Zheng T., Jiang M.Jia H., 2016. Biogas Production and Microbial Community Shift Through Neutral $\mathrm{pH}$ Control During the Anaerobic Digestion of Pig Manure. Bioresource Technology 217, 44-49.

[17] Dai X., Li X., Zhang D., Chen Y., Dai L., 2016.Simultaneous Enhancement of Methane Production and Methane Content in Biogas From Waste Activated Sludge and Perennial Ryegrass Anaerobic Co-digestion: The Effects of $\mathrm{pH}$ and $\mathrm{C} / \mathrm{N}$ Ratio. Bioresource Technology 216, 323-330.

[18] Mah R., Xun L.Y., Boone D., Ahringn B., Smithn P., Wilkie A., 1990. Methanogenesisfrom Propionate in Sludge and Enrichment Systems. In: Microbiology and Biochemistry of Strict Anaerobes Involved in Interspecies Hydrogen Transfer. Springer, pp. 99-111.

[19] Kim M., Ahn Y.H., Speece R., 2002. Comparative Process Stability and Efficiency of Anaerobic Digestion; Mesophilic vs. Thermophilic.Water Research 36, 4369-4385.

[20] Boone D.R., Xun L., 1987. Effects of pH, Temperature, and Nutrients on Propionate Degradation by a Methanogenic Enrichment Culture.Applied Environment Microbiology 53, 1589-1592.

[21] Pullammanappallil P.C., Chynoweth D.P., Lyberatos G., Svoronos S.A., 2001. Stable Performance of Anaerobic Digestion in The Presence of a High Concentration of Propionic acid. Bioresource Technology 78, 165-169.

[22] Nielsen H.B., Uellendahl H., Ahring B.K., 2007. Regulation and Optimization of The Biogas Process: Propionate as a Key Parameter. Biomass Bioenergy 31, 820-830. 